\title{
Santos, o porto do café: cidade, cotidiano e trabalho
}

\author{
MARIA IZILDA SANTOS DE MATOS*
}

\begin{abstract}
Resumo: Tendo em vista essas inquietações, o presente trabalho focalizará Santos, priorizando o período entre 1890 e 1930, procurando recuperar o processo de urbanização da cidade e as experiências e ações urbanas, recobrando toda uma diversidade e dinâmica das ocupações que absorviam o cotidiano de homens e mulheres no porto do café.
\end{abstract}

\begin{abstract}
In view of these anxieties, the present work focuses on the city of Santos, giving priority to the period between 1890 and 1930, trying to recover the process of urbanization, experiences and human activities and regaining all the diversity and dynamics of occupations which absorbed the everyday life of men and women who worked in the coffee harbor.
\end{abstract}

Palavras-chave: Santos. Processo de urbanização. Cotidiano, gênero e trabalho.

Key words: Santos. Urbanization process. Daily, gender and work.

Diferentes tendências da historiografia vêm se empenhando em focalizar os espaços urbanos, enfocando-os na totalidade constitutiva da trama histórica, presentes na memória coletiva e nas pedras da cidade. ${ }^{1}$ A cidade de Santos constituiu-se com múltiplos

* Doutora em história pela USP e professora titular da PUCSP, do Programa de Pós Graduação em História. Principais obras: MATOS, M. I. S. Trama e poder. 6. ed. Rio de Janeiro, Sette Letras, 2003; MATOS, M. I. S. Por uma história das mulheres. 2. ed. São Paulo: EDUSC, 2003; MATOS, M. I. S. Cotidiano e cultura: história, cidade e trabalho. São Paulo: EDUSC, 2002; MATOS, M. I. S; SOLLER, M. A. A cidade em debate. 3. ed. São Paulo: Olho d'Água, 2002.

1 O espaço urbano, no seu processo de transformação, é simultaneamente registro e agente histórico. Nesse sentido, deve-se destacar a noção de territorialidade, identificando o espaço enquanto experiência individual e coletiva, onde a rua, a praça, a praia, o bairro, os percursos estão plenos de lembranças, experiências e memórias. Espaços que, além de sua existência material, são também codificados num sistema de representação que deve ser focalizado pelo pesquisador, num trabalho de investigação sobre os múltiplos processos de territorialização, desterritorialização e reterritorialização. ROLNIK, Raquel. História urbana: história na cidade. In: FERNANDES, Ana; GOMES, Marco Aurélio. Cidade e história: modernização das cidades brasileiras nos séculos XIX e XX. Salvador: FAU/UFBA, 1992.

Estudos Ibero-Americanos. PUCRS, v. XXX, n. 2, p. 9-26, dezembro 2004 
referenciais: a praia, os morros, os canais, mas foi em torno do porto que a problemática da cidade foi delineada enquanto questão - a chamada "questão urbana". Esse processo constituiu-se atravessado pelos pressupostos da disciplina e da cidadania, passando a cidade a ser reconhecida enquanto espaço de tensões.

A primeira via a focalizar a cidade de Santos como uma "questão" foi a higiênico-sanitarista, conjugando o olhar médico com a observação/transformação do engenheiro (com destaque para Saturnino Brito), junto a uma política de intervenção de um Estado planejador/reformador, que procurou de todas as formas neutralizar o espaço, dar-lhe uma qualidade universal e manipulável, através da "racionalidade e objetividade" da ciência, que tem função-chave na sua luta contra o "arcaico pela ordem e progresso", caminhando conjuntamente ao desejo já latente e generalizado de "ser moderno", em que a cidade-porto aparece como sinônimo de progresso. Conjuntamente à questão urbana constroem-se a questão social com o surgimento da pobreza e a identificação do outro - o pobre, o negro, o imigrante.

Tendo em vista essas inquietações, o presente trabalho focalizará Santos, priorizando o período entre 1890 e 1930, procurando recuperar o processo de urbanização da cidade e as experiências e ações urbanas, recobrando toda diversidade e dinâmica das ocupações que absorviam o cotidiano de homens e mulheres no porto do café.

\section{O porto e a cidade}

A inauguração da ferrovia Santos-Jundiaí (1867) possibilitou um transporte mais regular, com menos riscos e maior grau de eficiência, impulsionando a expansão da cafeicultura e viabilizando o escoamento da produção. $\mathrm{O}$ comércio e a exportação do café passaram a ser centralizados em Santos, em detrimento de outros portos, desencadeando um intenso processo de urbanização e a expansão acelerada e contínua da cidade.

A crescente urbanização de Santos, que se consolidou como ponto de trânsito dos produtos de exportação-importação e dinâmico centro econômico e político, provocou transformações sociais num curto espaço de tempo e em ritmo acelerado, num quadro onde se interpenetraram a desintegração da escravidão, a grande imigração e a emergência do governo republicano. 
A centralidade da cidade enquanto porto tornava-a um imã que atraia toda uma população gerando uma crise que se manifestava no seu aspecto demográfico. O número e perfil da população foram alterados significativamente, por um processo de intensa imigração européia.

As ruas estreitas, o porto desarranjado, o trânsito de centenas de carroças carregadas de café e as epidemias marcavam o espaço urbano santista. Velhos problemas viam-se ampliados com o crescimento desordenado e o movimento agitado do porto, gerando o agravamento das condições ambientais, insuficiência de água e de esgotos, precária vigilância sobre os navios vindos de portos infectados, fazendo com que a cidade fosse constantemente assolada por violentos surtos de epidemias como a cólera, febre amarela, ${ }^{2}$ varíola, impaludismo e peste bubônica, atingindo particularmente a população pobre e imigrante. ${ }^{3}$

Essa população encontrava-se amontoada em moradias precárias, em becos, cortiços, vielas, praticamente sem água, esgoto e iluminação, enfim sem condições sanitárias, deixando-a vulnerável para contaminação e possibilitando a expansão das epidemias.

Apontava-se como um dos principais fatores das epidemias o grande número de cortiços localizados nas áreas mais centrais da cidade, erguidos nos pátios e nos quintais de qualquer jeito e tamanho, quase todos em estado deplorável; esses "cubículos" eram baixos, feitos de tábuas, cobertos com zinco, compostos de um só cômodo. Eram construídos às pressas "para albergar a numerosa imigração chegada em busca de trabalho remunerador e certo". Havia também o problema das cocheiras-cortiços, que em sua maioria eram também habitações coletivas, onde viviam cocheiros e suas famílias em palanques construídos sobre as baías. O grande número de cocheiras facilitava a difusão de ratos e pulgas, transmissores da peste bubônica. Como os outros cortiços, não tinham água nem esgoto, eram abafadas, insalubres. As águas paradas nos seus pátios difundiam o mosquito transmissor da febre amarela.

De 1890 a 1900 faleceram 22.588 pessoas atingidas por várias moléstias, 6.688 de febre amarela. ${ }^{4}$ A crise tornava premente o sa-

2 A cidade é marcada por grandes extensões de superfície plana, com dificuldades de drenagem o que favorecia a água parada e os "criadouros" do mosquito, vetor de transmissão da moléstia, em particular nos verões.

3 O obituário de Santos entre 1876-97, indica que dos mortos de febre amarela 78,7\% eram estrangeiros, dos quais $83,5 \%$ eram portugueses (carroceiros, ensacadores, carregadores, estivadores).

4 LOPES, Betralda. O porto de Santos e a febre amarela. São Paulo, 1974. Dissertação (Mestrado em História) - Faculdade de Filosofia, Letras e Ciências Humanas, Universidade de São Paulo. 
neamento, contudo o município não possuía recursos financeiros. As pressões cresceram, em particular do setor comercialexportador de café, a Associação Comercial de Santos dizia: "O saneamento de Santos torna-se uma necessidade inadiável para garantir não só a vida da população, mas altos interesses de ordem econômica". ${ }^{5}$ Por fim o governo do Estado assume a empreitada, era imprescindível manter o fluxo do café e para tanto o porto em funcionamento.

O crescimento do porto criou a necessidade de uma remodelação urbana, com uma atenção particular aos assuntos da saúde pública-sanitária. Essas medidas encontravam-se vinculadas aos novos pressupostos de higienização e somava-se ao desejo da Belle Époque de tornar o porto moderno e planejado, procurando eficiência e rapidez e pautada no binômio civilização e progresso. ${ }^{6}$

Várias propostas foram encaminhadas, enfrentando a burocracia e outros obstáculos políticos, por fim, foi aceito o projeto de Saturnino de Brito. ${ }^{7}$ Foram montadas duas comissões: uma sanitária, na sua maior parte coordenada pelo médico Guilherme Álvaro e outra de saneamento sob a liderança de Saturnino. ${ }^{8}$

O projeto se propunha "reparador absoluto das dificuldades", ele apresentava toda uma complexidade: um sistema de separação do esgoto das águas pluviais; um moderno sistema de esgoto projetava o esgotamento dos despejos pelo sistema de estações elevatórias acrescido da construção de uma grande ponte pênsil para levar as tubulações de esgoto e lançá-los ao mar; o enxugamento da planície e correção dos rios por meio da drenagem superficial composta de oito canais (mais um), de mar a mar, que aproveitando a força das marés possibilitava a limpeza evitando as águas estagnadas ${ }^{9} \mathrm{e}$ as inundações.

5 Boletim da Associação Comercial de Santos, Representação junto ao Governo de São Paulo, 1889.

6 ELIAS, Norbert. O processo civilizador. Rio de Janeiro: Jorge Zahar, 1994.

7 Francisco Saturnino de Brito nasceu em Campos/RJ, em 1864. Formado em engenharia civil, dedicou-se ao saneamento e urbanismo, é considerado patrono da engenharia sanitária no Brasil, atuou urbanisticamente nas cidades de São Paulo, Recife, Belém, Campos, Santos, tendo seu trabalho obtido reconhecimento internacional.

8 O projeto de Saturnino foi executado sob sua direção e dos engenheiros Miguel Presgrave, Joaquim T. de Oliveira Penteado e João Ferraz. As pontes ornamentadas sobre os canais foram projetadas por Carlos Lang e executadas por D. Savorelli. BRITO, Saturnino. Saneamento de Santos: projetos e relatórios. In: BRITO, S. Obras completas. Rio de Janeiro: Imprensa Nacional, 1943. v. 7.

9 Saturnino de Brito incorporou a concepção recente na época de Oswaldo Cruz e Guilherme Álvaro de que a febre amarela era transmitida pelo mosquito. 
Construídos de cimento armado, geralmente a céu aberto; gramados, internamente, na parte superior, com pontes e passadiços, os canais drenam o solo e recebem dos emissários águas pluviais, em tubos de cimento armado. Eles ocupam o espaço central das avenidas, facilitando a circulação e o arejamento urbano. Árvores nas calçadas laterais formam uma paisagem urbana amena com espaços de circulação para pedestres e veículos. A longa extensão dos canais e a largueza as avenidas favorecem a penetração das brisas marítimas no interior da ilha, refrescando-a. ${ }^{10}$

Em 1907, grande festividades marcaram a inauguração do primeiro e maior dos canais, o Canal 1 . Tinha-se motivos para comemorar: as epidemias estavam extintas, os canais garantiriam que elas não voltariam, o moderno sistema de esgoto tornou a cidade mais saudável e as inundações evitáveis, os negócios do café estavam revitalizados depois do Convênio de Taubaté e o porto funcionava a todo o vapor.

\section{Entre sacos e sobre rodas}

O porto, centro dinâmico da cidade, precisava ser constantemente modernizado e ampliado, a área tornara-se pólo de atração para os imigrantes recém-chegados. ${ }^{11}$ Em Santos, o contingente imigrante, em particular de ibéricos, foi incorporado em serviços estratégicos ao funcionamento básico da economia agroexportadora nos armazéns de café e docas, onde exerceram atividades de doqueiros, estivadores, ensacadores e carroceiros.

O intenso processo de urbanização era marcado pelas constantes demolições e construções, erigiam-se obras que definiam novos espaços, em geral estabelecidos a partir do porto e de suas necessidades. Os imigrantes ajudaram intensamente a construir a cidade trabalhando nas obras do porto e da cidade como pedreiros, carpinteiros, marceneiros e marmoristas. Artífices também se destacavam, fabricando artefatos de cimento e gesso, tacos de madeira para pisos, serralheiros executavam trabalhos em ferro para portões, janelas, grades e gradis.

10 ANDRADE, Wilma Therezinha. Santos: Canais traçam a história urbana. In: MATOS, Maria Izilda; SOLLER, M. Angélica (orgs.). Cidade em Debate. 3. ed. São Paulo: Olho d'Água, 2002.

11 Nas ferrovias e obras do porto de Santos, os imigrantes apareciam como preferenciais nos contratos desde 1890. Contrato Graffré-Guinle \& Cia com a Sociedade Promotora de Imigração, em 1892. 
As sacas de café, ao chegarem em Santos, eram descarregadas dos vagões dos trens e colocadas nos depósitos alinhados ao longo da via férrea; carroças e carretões estacionavam junto às portas numeradas desses depósitos e retiravam a mercadoria. Iniciava-se então o transporte pelas ruas estreitas da cidade até os armazéns particulares e o porto. Havia firmas organizadas, mas geralmente os carroceiros, quase todos imigrantes, dividiam entre si o transporte de café pela cidade.

O trabalho girava em torno da safra, quando o ritmo da atividade era intensificado. $\mathrm{O}$ número de carroças transitando cresceu em proporção direta ao aumento da quantidade de café exportado. Pelas ruas homens corriam ao lado das carroças puxadas a burro, sob um calor sufocante, fazendo às pressas a viragem, as misturas e o reensaque do café. No porto o embarque era feito carregando-se os sacos de café nas costas, e como num formigueiro humano os trabalhadores subiam e desciam com sacos nos ombros as pranchas do cais para o convés dos navios, ou de um navio para outro.

Carroceiros e carreteiros realizavam também inúmeras tarefas ligadas à circulação de alimentos e de mercadorias em geral e ao suporte à construção civil; faziam mudanças, transportavam pessoas, assegurando o funcionamento de serviços essenciais à rotina urbana. Todavia, o ganho era incerto, pois se em alguns dias arranjavam vários fregueses, em outros ficavam parados. Durante a safra o trabalho era intenso, mas em outros momentos do ano os ganhos eram eventuais.

\section{Em torno do porto}

O "sonho americano" e a atração exercida pelo porto prosseguiam, concentrando um significativo contingente de trabalhadores, toda uma massa que excedia largamente as necessidades do mercado. Como conseqüência, aviltavam-se os salários, criavam-se formas múltiplas de atividades temporárias e domiciliares, ampliavam-se o subemprego e o emprego flutuante de uma população que garantia a sua sobrevivência com ocupações casuais, mediante improvisação de expedientes variados, eventuais e incertos. Envolvendo esses trabalhadores numa trajetória que simultaneamente englobou participação e exclusão num processo de tensões e conflitos.

A crescente urbanização do porto e o aumento considerável da população geraram novas oportunidades para as atividades comerciais. Procurando trabalhar com um custo operacional mí- 
nimo, inúmeras famílias aproveitavam o quarto da frente de suas próprias casas para estabelecer pequenos armazéns de secos e molhados, açougues, adegas, quitanda de frutas e legumes, vendas, botequins. Esses estabelecimentos de pequeno e médio porte contavam com alguns poucos auxiliares, muitas vezes membros da família recém-chegados que se colocavam sob a tutela de parentes. Parcamente remunerados, submetia-se a longas jornadas, pagamentos incertos, muitas vezes recebendo somente roupa, alimentação e morando debaixo do mesmo teto do patrão. Exploração e paternalismo coexistiam dentro das casas comerciais. Nos processos crimes e nos jornais liam-se notícias como a do menor Alfredo Júlio Machado, português de 11 anos de idade que foi se queixar ao delegado de polícia por ter sido espancado pelo seu "amo" José Rodrigues Tavares, também português. ${ }^{12}$ Contudo, solidariedade e paternalismo não eram apenas formas de exploração, pois podiam ser também estratégias de sobrevivência e de lidar com os recursos possíveis na ocasião. ${ }^{13}$

Entre as diferentes categorias de vendedores ambulantes, que retiravam sua sobrevivência do comércio das ruas, havia aqueles que ofereciam gêneros de abastecimento fundamentais à rotina doméstica, comercializados em pequenas quantidades renovadas dia a dia. Utilizando-se de carrocinhas de madeiras, comercializavam verduras, cebola, batata, peixe, frutas, flores, ovos, leite, aves e pão.

Em Santos, a presença de imigrantes no comércio se fez sentir desde as atividades vinculadas ao café, importação e exportação de gêneros alimentícios, em especial vinhos, azeites e conservas, mas principalmente no pequeno comércio a retalho. Nesse setor trabalhavam com um pouco de tudo: trigo, arroz, milho, aveia e também alfafa, devido ao grande número de muares empregados no transporte e serviço portuário. ${ }^{14}$

Entre as pequenas profissões que predominavam no cenário urbano destacava-se o artesanato autônomo, em pequenas oficinas caseiras, localizadas em algum cômodo ou fundo de quintal, onde majoritariamente imigrantes trabalhavam como carpinteiros, ferreiros, ourives, sapateiros, calígrafos, alfaiates, seleiros, gravateiros. Dependendo do vulto do negócio, eram auxiliados pelo grupo

12 Diário de Santos, 6 dez. 1886.

13 THOMPSON, E. P. Tradición revuelta y conciencia de clase. Estudios sobre la crisis de la sociedade preindustrial. Barcelona: Crítica, 1984.

14 FRUTUOSO, Maria Suzel Gil. A emigração portuguesa e sua influência no Brasil: o caso de Santos. São Paulo, 1989. Dissertação (Mestrado em História) - Faculdade de Filosofia, Letras e Ciências Humanas, Universidade de São Paulo. 
familiar: mulher, filhos, algum conterrâneo ou agregado. $O$ fato de crianças serem desde pequenas introduzidas no aprendizado e utilizadas como ajudantes de seus pais fez com que muitas destas profissões adquirissem tradição hereditária, passando de geração a geração. Era o caso dos habilidosos e tradicionais marceneiros, serralheiros, alfaiates, costureiras e bordadeiras de origem imigrante.

Desde pequenos os filhos eram iniciados na rotina do trabalho. As crianças realizavam pequenos trabalhos, vendiam jornais, entregavam mercadorias, recados, cartas, eram engraxates, auxiliares em serviços domésticos, lojas e armazéns. A necessidade de as crianças desde cedo se engajarem no trabalho, casual ou nas fábricas, fruto das necessidades das camadas pobres, era visto como a possibilidade da obtenção de um ofício que lhes garantisse um futuro mais promissor.

Muitos imigrantes provenientes da Ilha da Madeira, habituados a residir em morros, passaram a ocupar terrenos de encostas, concentrando-se nos morros de São Bento e do Pacheco, onde fizeram trabalhos de terraceamento e de escoamento de águas. $\mathrm{Na}$ Madeira eram agricultores, habituados a plantar nas encostas, construíram escadas de pedra, muros de arrimo e formaram pequenos sítios e chácaras, cujos cuidados eram entregues quase que exclusivamente as mulheres, que plantavam verduras, hortaliças e legumes, criavam suínos, galinhas e gado leiteiro. Essa produção era toda comercializada na cidade de Santos pelas ilhoas. No cotidiano da cidade chamavam a atenção, transportando grandes volumes difíceis de equilibrar, os ilhéus comerciantes de palha e vime, utensílios largamente empregados pelas donas de casa como guarda-volumes.

Valendo-se de habilidades pessoais ou de expedientes, muitos trabalhadores se dedicavam a ofícios itinerantes, ligados à prestação de pequenos serviços domésticos de manutenção e conserto: eram jardineiros, capinadores de quintal, empalhadores, lavadores e enceradores de casas, desentupidores, limpadores de calhas, podadores de árvores, exterminadores de formigas, rachadores de lenha. Podiam receber pagamento em dinheiro ou simplesmente um prato de comida ou restos de alimentos, esse tipo de trabalho casual era desenvolvido como complementação salarial, ou então em função de momentos críticos.

Trabalhadores diaristas e ocasionais se reuniam em pontos da cidade para se informar de oportunidades de serviço. Em Santos, um desses pontos de encontro de toda uma população multiétnica e diversificada - pescadores, marinheiros, portuários, empregadas 
domésticas e trabalhadores eventuais - era o Largo da Branca, onde $\mathrm{o}$ porto $\mathrm{e}$ a cidade se misturavam. As pessoas se aglomeravam no local, comprando - peixe, frutas, verduras e outros gêneros -, conversando, bebendo, brigando, trabalhando (catadoras de restolho), trocando informações sobre possibilidades de empregos e pequenos biscates.

\section{Perfis urbanos no porto do café}

A cultura urbana santista contou entre com o marcante papel da mulher local: negra, índia ou imigrante, ela foi elemento de suma importância no espaço da cidade, do porto e dos domicílios, trabalhando e resistindo. As mulheres santistas sempre estiveram presentes no universo do trabalho, nas fábricas, nos estabelecimentos comerciais familiares ou em atividades urbanas variadas.

O cotidiano do trabalho portuário afetava diretamente a rotina de vida e trabalho das mulheres em Santos. O trabalhador portuário morava perto do local de atividade, e o ritmo instável, irregular e sazonal do trabalho permitia um ir e vir entre a casa e o porto até mais do que uma vez ao dia. A rotina doméstica das esposas desses trabalhadores era diretamente afetada pelas horas que seus maridos trabalhavam e pelo tipo de carga com que lidavam. O salário do trabalhador do porto flutuava conforme a sazonalidade, o que criava um impacto no orçamento familiar. Com as colunas arqueadas e os pulmões corroídos, doqueiros e estivadores tinham que abandonar precocemente as atividades da estiva. 15 Assim, suas mulheres, além de desempenharem as atividades domésticas, tinham que compensar a incerteza do ganho e a inatividade precoce dos maridos trabalhando como catadoras de café e de restolho, nos porões, armazéns e no mercado, na costura dos sacos de café, ou como empregadas domésticas particularmente lavadeiras. ${ }^{16}$

As trajetórias urbanas dessas mulheres aparecem nas memórias de Benedita Ribeiro dos Santos, nascida em São Sebastião em 1902, neta de escravos, relembra:

Trabalhei trinta anos como catadora de café num armazém, às vezes, eu ficava a noite inteira catando café. Quando um navio tinha que sair de manhã carregado de café eu trabalhava a noite inteira.

15 GITAHY, M. Lucia C. Ventos do mar: trabalhadores do porto, movimento operário e cultura urbana em Santos, 1889-1914. São Paulo: Ed. Unesp, 1992.

16 As catadoras de café nos armazéns do porto não ganhavam nada por isso ficando com parte do café que vendiam a retalho. 
Foi o último trabalho que eu tive. Eu trabalhei lá muitos anos até me aposentar. Mas o salário era ruim, pior do que nas lavanderias a vapor. Eu trabalhei muito tempo nas lavanderias a vapor também. Nós lavávamos as roupas dos navios e mandávamos de volta a bordo limpas e engomadas, eu trabalhava com um ferro elétrico e pesado... Nas lavanderias, a gente tinha muito trabalho. Eu entrava às sete horas da manhã, parava só pra almoçar e saía às seis da tarde. Quando eu voltava pra casa, eu ainda levava roupa pra lavar e passar por minha conta. Eu pegava esta roupa lá na zona, onde ficava aquela fila de casas de mulheres no cais. Elas usavam saias armadas. Eu passava lá bem cedinho, de manhã, antes de ir pro meu trabalho. Devia ter outras lavadeiras fazendo o mesmo porque as casas eram muitas e as mulheres tinham cada roupa linda! Você precisa ter visto as anáguas! Eu tinha que colocar uma tábua por dentro para não amarrotar tudo com o ferro. Era uma trabalheira! Hoje acabou tudo. Coitadas das mulheres ficam aí de noite pelas ruas...17

A lavagem de roupa era uma das funções mais essenciais em qualquer moradia. As famílias de posses usavam grande quantidade de roupa branca no seu cotidiano: roupas de cama, mesa e banho, e também as próprias roupas de homens, mulheres e crianças, que em geral exigiam cuidados especiais no lavar, passar e engomar.

Por outro lado, o movimento intenso do porto, com um grande número de navios entrando e saindo, em particular nos momentos de safra cafeeira, criava a necessidade de que as roupas de bordo fossem lavadas, tornando-se essa atividade uma possibilidade de ganho para mulheres. Elas agitavam o porto, movimentavam a cidade, pois em tempo hábil, antes da partida dos navios, as roupas deveriam retornar a bordo limpas, passadas e engomadas.

As lavadeiras, algumas delas chefes de família, procuravam ampliar as fontes de subsistência num esforço para trazer à família recursos adicionais, vitais em caso de crise. Isto acarretou um aumento da atividade feminina, levando a essas mulheres a reproduzir as ocupações desenvolvidas nos quadros domésticos, como lavar, passar e engomar, atividades que passaram a constituir uma opção de ocupação remunerada, impondo-lhes uma jornada de trabalho ampla numa extensão de sua própria atividade doméstica e com ganhos parcos. Assim, procurando harmonizar o exercício da maternidade com atividades outras que lhes permitissem garantir a subsistência, as mulheres recorriam, entre outras, a esta estratégia de sobrevivência.

17 Lembranças de D. Benedita Ribeiro dos Santos. Banco de Memórias de Famílias Negras, PUCSP, p. 4. 
Além de serem reconhecidas como mulheres dispostas para o trabalho, eram tidas como "quem não leva desaforo para casa", pois cotidianamente se envolviam em brigas e acabavam parando na polícia. Os conflitos envolvendo lavadeiras estão presentes na imprensa diária e nos relatórios dos chefes de polícia. Umas brigavam porque passaram à sua frente na utilização da bica, porque "sujou a minha roupa no quaradouro", "porque me deu com o tamanco na cabeça", "por ter retirado um bambu de estender roupa e ter insultado com palavras obscenas", além das constantes disputas por espaço nas cordas de estender roupa.

Todavia, o cotidiano dessa atividade não se pautava apenas pelos conflitos. Era costume bastante difundido o canto das lavadeiras que ritmava o trabalho de lavar, esfregar, torcer e bater. O trabalho coletivo revigorava vínculos de vizinhança e camaradagem que significavam lazer, solidariedade material e afetiva, mas também controle e regulação das condutas e procedimentos.

As lavagens de roupa, como outros serviços domésticos eram vistos em grande parte como "funções femininas", 18 que eram as que exigiam menor esforço físico, monótonas e praticamente invisíveis aos olhos dos membros da família, além de desprestigiadas socialmente. Algumas mulheres não se submetiam a esse discurso que lhes recusava a competência, a autoridade, como D. Benedita Ribeiro dos Santos:

Eu aprendi a passar roupa quando eu era menina com minha mãe... Hoje meus meninos dizem que eu não sei nada, só porque eu não sei ler. Mas eu sei tudo de trabalho na roça, lavar, passar, costurar, tudo sobre café, sobre todo tipo de trabalho. Eu vi muitas coisas na minha vida...19

Ao contrário de D. Benedita, a maior parte das próprias mulheres interiorizava essa banalização de seu trabalho, desvalorizando as suas funções. A maioria via sua atividade como um biscate, uma "ajuda" prestada ao marido, mesmo quando a renda auferida se equiparava à percebida pelo homem. Enfim, era um trabalho não contabilizado, mal-remunerado e não reconhecido. As fronteiras, para essas mulheres, entre o mundo do trabalho e o da vida privada não eram muito nítidas, pois entre esses dois mundos havia uma complexa relação de complementaridade.

18 PERROT, Michelle. Qu'est-ce qu'un métier de femme? In: Le Mouvement Social, Paris, Les Éditions Ouvrières, n. 140, juil.-sept. 1987.

19 Lembranças de D. Benedita Ribeiro dos Santos. Banco de Memórias de Famílias Negras, PUCSP, p. 6. 
Todavia, os padrões de fragilidade feminina e trabalho leve podem ser revistos se observarmos o cotidiano das lavadeiras, carregando pesadas trouxas de roupa, das engomadeiras, dias a fio utilizando o ferro de carvão e os ferros de entiotar. A imagem difundida sobre de lavagem de roupa como um trabalho leve, não especializado, sem riscos e inofensivo à saúde entra em contraste com as informações coletadas. Depois dos carroceiros, eram as lavadeiras que mais sofria acidentes, que muitas vezes chegavam a ficar incapacitadas. As lavadeiras eram atingidas principalmente por ferimentos nas mãos, causados por cortes e penetração de corpos estranhos, mas havia também casos de afogamentos nos poços. As que também exerciam a função de passadeira eram freqüentemente se queimavam com o ferro de passar. Além das contusões e escoriações, eram comuns as rupturas de varizes, principalmente entre as mais idosas, demonstrando como o trabalho era pesado.

Entre as doenças que atingiam esse grupo, além da tuberculose e o reumatismo, que se agravava pelo excesso de trabalho, falta de repouso e alimentação adequada, numerosos eram os ataques de nervos, conseqüência, provavelmente, de tensões nas relações cotidianas.

Em Santos, a construção do porto e o saneamento da cidade foram obras interligadas no quadro de transformação urbana e fizeram parte de um processo através do qual se reorganizaram o trabalho e a própria face da cidade. No combate às epidemias, nas desinfecções e no controle sobre cortiços, cocheiras e lavanderias públicas trabalhavam conjuntamente a Cia. Docas de Santos e a Comissão Sanitária, que aliadas à Comissão do Saneamento procuravam disciplinar o traçado da rede de esgotos e das ruas.

As autoridades higiênicas santistas também alertavam que as mulheres que recolhiam roupa para lavar em tinas comunitárias nos cortiços (considerados focos de contaminação) "misturavam as roupas de todas as gentes" e contaminavam as famílias, reforçando a idéia corrente de que o pobre contaminava o rico. ${ }^{20}$ As lavadeiras foram acusadas pela propagação das pestes e epidemias que assolavam o porto. Alegava-se que a mistura das roupas na lavagem possibilitava o contágio, trazendo dos navios as pestes. A água suja das lavagens que escorria pela cidade também era considera-

20 No setor médico-sanitarista acreditava-se que febres e epidemias (por exemplo, a febre amarela) eram transmitidas pela roupa; assim, as lavadeiras, que em seus domicílios misturavam as roupas sujas, eram verdadeiramente perseguidas. 
da grande foco de propagação. ${ }^{21}$ Procurou-se então controlar ou extinguir esse tipo de ocupação, difundindo-se as lavanderias a vapor.

Tentava-se de diferentes formas normatizar essa atividade, que gradativamente, mas não sem resistência, perderia o seu caráter público e externo: a prática de quarar em espaços públicos e de secar nas pontes e praças da cidade passou a ser realizada prioritariamente, embora não exclusivamente, nos domicílios dos patrões, onde as lavadeiras passaram a trabalhar como mensalistas e, principalmente, diaristas. Incorporada ao cotidiano, essa prática se corporificou no ditado popular: "roupa suja se lava em casa".

\section{No porto, mas porta adentro}

Numa conjuntura de alta rotatividade da mão-de-obra, fruto de um mercado de trabalho com flutuações cíclicas, os serviços domésticos eram uma das atividades que absorviam um dos maiores contingentes de trabalhadores, particularmente mulheres e menores. Mulheres casadas ou solteiras, imigrantes ou nacionais, brancas ou negras, sós ou acompanhadas com filhos, empregavase para diversos serviços em casas de família.

$\mathrm{Na}$ orla da praia e em ruas próximas, as mansões inglesas e americanas tinham seus extensos gramados e belos jardins quase sempre cuidados por jardineiros, também empregados como cocheiros e motoristas. Diante disso, as famílias brasileiras também passaram a contratar imigrantes como empregados domésticos, mas como aquelas pagassem salários baixos e não respeitassem o horário de trabalho, estes acabavam por preferir os patrões estrangeiros. ${ }^{22}$

As criadas enfrentavam uma dura rotina doméstica, começavam a trabalhar desde a madrugada e, dependendo das necessidades, só paravam altas horas da noite, ficando à disposição para serviços eventuais. Nas casas geridas por patroas exigentes, as criadas se submetiam a um programa rígido de trabalho, onde se interpenetravam tarefas variadas e de certa forma sobrepostas, em geral realizadas longe da presença de outros membros da família, como um serviço invisível, embora indispensável.

21 SANTOS, Martins Francisco. História de Santos. São Paulo: Empreza Gráphica da Revista dos Tribunaes, 1937, v. 2, p. 29.

22 FRUTUOSO, Maria Suzel Gil. A emigração portuguesa e sua influência no Brasil: o caso de Santos. São Paulo, 1989. Dissertação (Mestrado em História) - Faculdade de Filosofia, Letras e Ciências Humanas, Universidade de São Paulo. 
As transformações no espaço urbano e no interior da família são indissociáveis. A ampliação do campo de ação da medicina, e em particular da higiene, influenciou diretamente a cidade e as casas, e nestas o trabalho doméstico, que se alterou nessa passagem de século em relação estreita com os surtos de febre e epidemias e com a difusão de novas normas de higiene, canalização de água, ordenação do comércio de abastecimento. A organização do trabalho nas casas também se tornou dependente dos horários das escolas e do trabalho. ${ }^{23}$

Os trabalhos na cozinha também eram árduos. Cozinhavase no fogão de lenha, o que exigia grandes habilidades não apenas nos pratos que se preparavam, mas também no equipamento que se usava. ${ }^{24} \mathrm{O}$ cotidiano do trabalho na cozinha foi se alterando com a paulatina introdução dos fogões a gás e da água encanada. As práticas alimentares também se alteraram consideravelmente, a alimentação tornou-se mais variada e, correlativamente, o trabalho de preparação tornou-se maior. Além do preparo do alimento (abate, limpeza e preparação de aves e animais de pequeno porte), os serviços de cozinha incluíam o fazer pão, pilar e moer o milho e o arroz; pilar, torrar e moer o café; refinar o açúcar e o sal, preparar a banha, defumar carnes e até fazer sabão. Numa cidade centrada no porto, o urbano e o rural se interpenetravam, o público e o privado se redefiniam, o trabalho doméstico também poderia incluir o trato do galinheiro, da horta e do pomar, e até vendas ocasionais de excedentes desses produtos.

A rotina se diferenciava de casa para casa. Numa residência com muitos empregados havia rigorosa hierarquia e delimitações de funções, sendo que alguns mais especializados chegavam a se recusar a realizar serviços para os quais não tinham sido contratados. A copeira, além do serviço de mesa, era encarregada dos cuidados com as louças, cristais e prataria. As governantas eram

23 As transformações no espaço urbano vêm atraindo a atenção de vários historiadores, mas o foco do espaço privado não vem merecendo a devida análise. A expansão urbana e capitalista desse período trouxe o aparecimento da noção de rentabilidade, eficácia do trabalho em todos os domínios, inclusive no espaço interior, destacandose a importância da limpeza e da higiene para saúde e bem-estar da família e com ela a responsabilidade da dona de casa. Nesse momento se expandem os manuais e revistas que fornecem as normas de como executar e/ou organizar os serviços do lar. Cf. MATOS, Maria Izilda Santos de. Cotidiano e cultura: história, cidade e trabalho. São Paulo: EDUSC, 2002.

24 GRAHAN,Sandra Lauderdale. Proteção e obediência: criadas e seus patrões no Rio de Janeiro - 1860-1910. São Paulo: Cia. das Letras, 1992, p.46-7. 
empregadas em lares sem dona de casa, de homens viúvos e solteiros, ou por famílias que desejassem entregar toda a responsabilidade sobre os demais criados para uma senhora. Como mostram os anúncios na imprensa, as alemãs eram as preferidas para essa função, por sua suposta autoridade e dinâmica de trabalho.

Eventualmente, também utilizavam servidores diaristas ou temporários, como enceradores, lavadores de vidraças, costureiras, lavadeiras e engomadeiras, para complementar o trabalho da única criada. Todavia, o mais comum era ter uma única empregada que realizava todos os serviços: lavar, engomar, cozinhar e arrumar. As mais experientes faziam verdadeiros malabarismos para executar todas as suas obrigações. Mesmo assim, para muitas o trabalho doméstico significava também a possibilidade de obter alimentação e casa, além de outros benefícios. Quando a casa era farta, os empregados, a despeito do valor ínfimo dos salários, conseguiam condições de alimentação e moradia melhores que as de muitos outros trabalhadores.

\section{Por mãos femininas}

O trabalho domiciliar feminino foi intensamente utilizado em Santos, através de atividades como: costura, bordados e manufatura de flores, elaboração de enxovais de cama e mesa, bordados para noivas e batizados, ${ }^{25}$ confecção de roupas, mercadorias de carregação e costura da sacaria para o café. O baixo custo deste trabalho, as especificidades da mão-de-obra utilizada, a dispersão das costureiras como fator de controle, a disponibilidade de trabalhadores que se sujeitassem a essa atividade eram fatores para a persistência dessa ocupação.

Realizado sob condições pouco propícias, o trabalho a domicílio se caracterizava como uma atividade temporária, tendo seu ritmo intensificado em certos momentos. Sem horário fixo, a costura poderia estender-se muito além do número de horas comum ao trabalho fabril. A remuneração era baixa e por peça, sofrendo um achatamento nos momentos de queda no preço e/ou de aumento da oferta de mão-de-obra.

25 As mulheres que vinham da Ilha da Madeira, eram consideradas hábeis costureiras e traziam o bordado como atividade tradicional, passada através de gerações, à medida que se tornavam conhecidas, começaram a receber encomendas. $\mathrm{O}$ trabalho era parcamente remunerado, embora os bordados depois de prontos alcançassem altos preços nas lojas. 
O local de trabalho era a própria residência das trabalhadoras: nos morros, nos cortiços, alguns cubículos estreitos, aglomerados com péssima situação sanitária, pólos de propagação da tuberculose, e com má iluminação, o que causava males irremediáveis à visão.

A costura, em contraposição a outras atividades, permitia certa flexibilidade de horário, liberdade de ir e vir. Criava também o prazer do convívio em grupo, pois freqüentemente, nos pátios dos cortiços, nos morros, mulheres costuravam, bordavam e conversavam nas chamadas "trempas". Eram momentos de encontro, de troca de informações, receitas e remédios. A noção de autonomia, fuga das estruturas hierárquicas, dos condicionamentos de tempo e ritmo de trabalho concorria para aumentar a disponibilidade e oferta dessa mão-de-obra. Isso não significa, no entanto, que inexistissem formas de controle, já que um certo número de peças deveria ser entregue num prazo determinado e mantendo um perfil de qualidade.

Mas mesmo frente a essas condições a costura e outras atividades domiciliares femininas se apresentavam como opção para as mulheres, num certo período de sua trajetória de vida, possibilitando conciliar o ritmo, o espaço e o tempo do trabalho doméstico com uma atividade remunerada e sem horário fixo.

Todas essas atividades giravam majoritariamente nos em tornos do porto, de alguma forma o centro da cidade, mas as relaçõestensões entre o porto e a barra, o trabalho e o lazer, passariam por mudanças.

\section{De costas para o porto}

Tentativas de focalizar o porto do café implicam em um trabalho repleto de dificuldades para os que ousam enveredar por campos minados de incertezas, repletos de controvérsias e ambigüidades. A implantação da ação reformadora num quadro de transformações urbanas do porto foi encaminhada através do projeto do engenheiro Saturnino de Brito, apresentando marcas em Santos, a ponto de podermos dividir sua história em duas etapas: antes e após o saneamento. Os trabalhos da Comissão foram iniciados em 1905 e já em 1907 foi inaugurado o Canal 1, em 1908 já eram 45.000 metros de canais, que por sua utilidade e beleza passaram a marcar as memórias afetivas da cidade.

A cidade higienizada diversificava suas funções, as chácaras da praia cedem lugar a mansões da elite. Já na primeira década do século foi construído o luxuoso Hotel Parque Balneário, a praia passou a ser sinônimo de lazer, atraindo moradores e visitantes. 
Assim, o espaço da praia rapidamente se distinguia de anos anteriores, um areal procurado pelos que procuravam bons ares ou defendiam os milagres curativos do banho de mar. No século XIX, o banho de mar não era hábito social difuso, mas terapia recomendada para tratamento de saúde.

Imagens do século XIX já exibem banhistas santistas, aos poucos ocorreu uma gradativa ampliação da ida à praia como forma de lazer e prática esportiva, mas somente depois da década de 40 é que a freqüência às praias se generaliza, sendo elas representadas enquanto espaço de beleza, sensualidade e prazer.

Em 1947 foi inaugurada a Via Anchieta, que aproximou Santos de São Paulo e do interior. Apesar de se manter a importância das atividades portuárias, a partir daí a função de veraneio se acentuou na cidade, gerando transformações urbanísticas e arquitetônicas com a verticalização da orla da praia. O processo acelerado de transformação relaciona-se à própria ocupação urbana primeiramente vinculada a uma elite e posteriormente a uma expansão de imóveis mais acessíveis, atraindo para a área outros setores sociais.

A cidade volta as costas para o porto.

\section{Bibliografia e fontes de referência}

ALVARO, Guilherme. A campanha sanitária de Santos: suas causas e seus efeitos. São Paulo: Casa Duprat, 1919.

ALVARO, José Ribeiro de. A expansão urbana de Santos. In: Baixada Santista. São Paulo: EDUSP, 1965.

ANDRADE, Wilma T. F. de. O discurso do progresso: a evolução urbana de Santos-(1870-1930). São Paulo, 1989. Doutorado (História) - Faculdade de Filosofia, Letras e Ciências Humanas, Universidade de São Paulo.

—. Coleção Santista: o que se pode ler sobre Santos. São Paulo: Ed. Loyola, 1977.

. Santos Canais traçam a história urbana. In: MATOS, Maria Izilda; SOLLER, M. Angélica (orgs.). Cidade em debate. São Paulo: Olho d'Água, 2002.

ARAUJO FILHO, José Ribeiro de. Santos: o porto do café. Rio de Janeiro: Instituto Brasileiro de Geografia e Estatística, 1969.

Boletim da Associação Comercial de Santos, Representação junto ao Governo de São Paulo, 1889.

BRITO, Saturnino. Saneamento de Santos: projetos e relatórios. In: BRITO, S. Obras completas. Rio de Janeiro: Imprensa Nacional, 1943. v. 7.

BURKE, Peter (org.). A escrita da história: novas perspectivas. São Paulo: Ed. UNESP, 1992.

CERTEAU, Michel de. A invenção do cotidiano. Petrópolis: Vozes, 1994. 
CHARTIER, Roger. A história cultural: entre práticas e representações. Lisboa; Rio de Janeiro: Difel; Bertrand do Brasil, 1990.

DA MATTA, Roberto. A casa e a rua: espaço, cidadania, mulher e morte no Brasil. Rio de Janeiro: Brasiliense, 1985.

FRUTUOSO, Maria Suzel Gil. A emigração portuguesa e sua influência no Brasil: o caso de Santos, São Paulo, 1989. Dissertação (Mestrado em História) - Faculdade de Filosofia, Letras e Ciências Humanas, Universidade de São Paulo.

FURTES, E.A. Saneamento da cidade e porto de Santos. São Paulo: Typografia do Diário Official, 1895. [IHGSP].

GITAHY, Maria Lucia Caira. Ventos do mar. São Paulo: Ed. UNESP, 1992.

GRAHAN, Sandra Lauderdale. Proteção e obediência: criadas e seus patrões no Rio de Janeiro - 1860-1910. São Paulo: Cia. das Letras, 1992.

LOPES, Betralda. O porto de Santos e a febre amarela. São Paulo, 1975. Dissertação (Mestrado em História) - Faculdade de Filosofia, Letras e Ciências Humanas, Universidade de São Paulo.

MATOS, Maria Izilda Santos de; SOLLER, Maria Angélica (orgs.). A cidade em debate. 3. ed. São Paulo: Olho d'Água, 2002.

MATOS, Maria Izilda S. de. Trama e poder - um estudo sobre as indústrias de sacaria para o café (1888-1934). 6. ed. Rio de Janeiro: Sette Letras, 2003.

. Na trama do cotidiano. In: Cadernos Ceru, n. 5, série 2, 1994, p. 13-27.

PERROT, Michelle. Qu'est-ce qu'un métier de femme? In: Le Mouvement Social, Paris, Les Éditions Ouvrières, n. 140, juil.-sept. 1987.

PINTO, Alfredo M. Santos. Santos: Typografia Imprensa Popular, 1898.

ROLNIK, Raquel. História urbana: história na cidade. In: FERNANDES, Ana; GOMES, Marco Aurélio. Cidade e história: modernização das cidades brasileiras nos séculos XIX e XX. Salvador: FAU/UFBA, 1992.

SALLES, Iraci G. Trabalho, progresso e a sociedade civilizada. São Paulo: Hucitec, 1986.

SANTOS, Martins Francisco. História de Santos. São Paulo: Empreza Graphica da Revista dos Tribunaes, 1937, v. 2.

SILVA SOBRINHO, J. Costa da. Santos noutros tempos. São Paulo: Instituto Histórico e Geográfico de Santos, 1953.

Romagem pela terra dos Andradas. São Paulo: Freitas Bastos, 1957.

. Materiais para história de Santos. Santos: Arquivo Histórico Municipal de Santos, s.d.

THOMPSON, E. P. Tradición, revuelta y consciencia de clase. Estudos sobre a crisis de la sociedad pré industrial. Barcelona: Critica, 1979.

VICTORINO, Carlos. Santos: reminiscencias. São Paulo, 1904. 